\title{
EDITORIAL
}

\section{Road Traffic Accidents in Bangladesh}

There has been an alarming rise in road traffic accidents in Bangladesh over the past few years and has become a national problem. Everyday around eight persons die in road traffic accidents. The actual rate of fatality is likely to be even higher. The number of accidents has increased by $43 \%$ between 1982 and 2000 , while the number of fatalities has increased by around $400 \%$ within the same period ${ }^{1}$.It increases more on the eve of festivals. In the last 21 years 84 thousand road traffic accidents occurred, 56 thousand people died and 63 thousand injured.

At least 4,284 people were killed and 9,112 others injured in road traffic accidents across Bangladesh in 2017. A total of 3,412 people died and 8,572 others injured by this in 2016. The number of accidents increased by $15.82 \%$ and death increased by $25.56 \%$ in 2017 compared to $2016^{2}$.A total of 2,123 people died and 5,558 others were injured in the first four months of this year ${ }^{3}$. But only thisnumerically shocking statistics mayfail to reflect the social tragedy related to each life lost in road traffic accidents.

Road traffic accidents in our country is multifactorial. Rapid urbanization and motorization can be identified as vital factors leading to higher number of road traffic accidents. Reasons behind the increased number of accidents and casualties includereckless driving, over speeding, overloading, overtaking, violating laws, illegal and dangerous competition, long-time driving without break, use of drug and alcohol, incompetency of the driver, hazardous road, lack of proper design and construction of the road, lack of safety measures, lack of road maintenance, poor implementation of traffic rules and regulations, lack of awareness among the people,presence of market near busy highways andplying of three wheeler-vehicles, motorbikes, and locally-made mechanized vehicles.

RTA alone costs $1 \%, 1.5 \%$ and $2 \%$ of the gross national product (GNP) of low, middle, and high income countries respectively. For low and middle income countries, this exceeds the total developmental aid received. According to the Guardian, the country loses an estimated 1.2 billion pounds due to road traffic accidents per year, equivalent to $2 \%$ of GDP and all of the foreign aid that Bangladesh receives annually. According to UNICEF, roughly 38,000 children become orphans every year because of road fatalities. In broad terms the economic burden of injury can be summarized into areas like: a. Medical costs- prehospital care, transport, emergency medical services, hospitalization, investigations,drugs and appliances, rehabilitation, mental health and administrative costs of medical care. b. Costs of damage to or loss of property. c. Indirect costs like lost productivity, lost wages of victims, productivity losses by families and friends involved in care, travel delay for uninjured travelers that results from road crashes, productivity losses of employers on account of hiring and training replacement workers. d. Cost in terms of quality of life- economic value of pain and suffering, disability and death.

The traffic police department has a crucial role to play in identifying and holding accountable reckless driving, speeding and unstable or overloaded vehicles. The maintenance, repair and expansion of roads coupled with setting up dividers on national highways, cautioning signals for hazardous locations, disseminating information on driving and road safety to masses through media and exemplary punishment for violating traffic laws are some of the main areas that need to be worked on rigorously by the government.

As citizens, we also have a role to play in ensuring road safety. While travelling in public transports, passengers should protest and stop speeding and reckless driving by bus and taxi drivers. Owners of motor vehicles should ensure that employed drivers have genuine licenses, they are properly trained and drive responsibly. Road safety education to pedestrians, especially the children, by community leaders is also a good way to promote road safety. Some road safety initiatives in Bangladesh are the adoption of National Land Transport Policy (NLTP), establishment of 
National Road Safety Council (NRSC), establishment of road safety cell and district road safety committee, establishment of Accident Research Institute (ARI) at BUET, establishment of highway police, formation of road safety voluntary \& advisory group, preparation of national road safety strategic action plans, training of road safety professionals, NGO initiatives towards road safety and geometric improvement of roads

In conclusion it can be said that, the unsafe roads are a key public health challenge. One of the goals of development is to improve health outcomes by reducing premature mortality, injuries and disability. The high rate of fatal accidents in Bangladesh is an alarming issue and time has arrived to confront this multi-sectorial challenge. For a developing country like Bangladesh, allowing its citizen to perish to road traffic accidents is not only tragic but also unacceptable. Many steps has been taken by government for improving road safety. However, not many tangible results have been achieved so far. It is imperative to review the measures adopted to identify the problems of implementation and improve or modify them so that they can be more effective.

(J Bangladesh Coll Phys Surg 2018; 36: 137-138) DOI: http://dx.doi.org/10.3329/jbcps.v36i4.38178

\section{Professor Abul Bashar Mohammed Khurshid Alam}

Professor, Dept. of Surgery

Dhaka Medical College

Ward No-219, Dhaka.

\section{References:}

1. Louis Burger Group-BCL. Strategic Transport Plan. Dhaka Transport Coordination Board, Ministry of Communications, Government of Bangladesh. (2005). (draft).

2. The National Committee to Protect Shipping, Roads and Railways (NCPSRR) report.

3. Bangladesh JatriKalyanSamity report. 